\title{
Man-Eaters of Kumaon: a Critique of Modernity
}

\author{
Parul Rani \& Nagendra Kumar \\ Department of Humanities and Social Sciences, IIT Roorkee. Email: parulnet.e@gmail.com
}

Received February 14, 2017; Revised April 14, 2017; Accepted April 20, 2017; Published May 7, 2017.

\begin{abstract}
The present paper attempts to link the animals' colonization with modernity as a form of European 'mindset' through a short story collection of Jim Corbett, Man Eaters of Kumaon. The focus is laid on the disfigurement of the non-human entities in the colonial anthropocentric advancement; manifested through the hunting practices in colonial India. This study analyzes: first, the hunting practices as a power mechanism of colonials to dominate native subjects: human and non-human, and traces the conflict it creates between human life and wildlife. It also studies the sporting and systematic controlling over the wild animals with the help of technological enrichment. Secondly, it investigates the ambiguous presence of Jim Corbett, primarily a hunter, vacillating between his duties for the British colonial administration and for the native people, as a sahib.
\end{abstract}

Keywords: wildlife, modernity, Jim Corbett, colonialism, colonial ideology.

\section{Introduction}

The present paper investigates the connection between the modernity of the European world, being manifested in their treatment of nature in India during the colonial period and its aftermath in the context of Indian wildlife in Kumaon region, as depicted by Jim Corbett. This study of Man Eaters of Kumaon is a critique of modernity, which liberalizes the humans to act freely and individually as the colonials are trying to establish their supremacy over the animals through hunting practices. Modernity, as a break from tradition brings a change in the attitudes and thinking with a focus on: intellectuality, rationality, material progress, individuality, humanistic approach and scientific progress. It introduced human at the centre, instead of a part of the whole system. It reminds of what Friedrich Nietzsche termed his book Human, All Too Human. Daniel Bell marked modernity with, "What defines modern is a sense of openness to change, of detachment from place and time, of social and geographical mobility, and a readiness, if not eagerness, to welcome the new, even at the expense of tradition and past." (qtd in Cooper, 2005, p.120) Although all the modernistic follies are interrelated, in the context of the text ManEaters of Kumaon, the focus is laid on the humanistic approach and its complex relationship with the tradition of hunting or shikar, a form of rule during the colonialism in India. McCarthy says "The conception of "man'...is, according to the radical critics of enlightenment, at the core of Western humanism...” (qtd. in Habermas,1998, viii). The priority, given to the humans, in the social, intellectual and cultural actions or practices has produced a subject centered world and its influences are worldwide. "The critique of subject-centered reason is thus a prologue to the critique of a bankrupt culture" (McCarthy, qtd. in Habermas, 1998: viii) The anthropocentric perspective fabricates wildlife in colonial India. The disunity between the inner and the outer environment of the Europeans determined the form of their modern culture. The sense of

(c) AesthetixMS 2016. This Open Access article is published under a Creative Commons Attribution Non-Commercial 4.0 International License (http://creativecommons.org/licenses/by-nc/4.o/), which permits non-commercial re-use, distribution, and reproduction in any medium, provided the original work is properly cited. For citation use the DOI. For commercial re-use, please contact editor@rupkatha.com. 
freedom from all essential factors was crucial to their indifferent demeanor towards the nature. G.W.F. Hegel quoted of the modern thought, "the separation of the religious from the secular interest, i.e., from the special interest of individuality; and the ground of this separation lies in their inmost soul, which has lost its independent entireness of being, its profoundest unity" (Hegel, 1991, p.440)

Jim Corbett, a renowned hunter cum conservationist, discloses his hunting experiences in his first short story collection Man-Eaters of Kumaon, appeared in 1944. He is one of the very few writers who made hunting and animals the subject of discourse in his writings. Other hunting based writings like Some Signposts to Shikar (1932) by RDT Alexander and Leaje, and Guide to Shikar on the Nilgiris (1924) by Big Bore, also appeared at the same time. Unlike his contemporaries, Corbett's minute details of the Indian jungles, animals and rural folk make it distinct from others and comprise a compact phenomenon of the colonial India. The detailed description the Kumaon region is the instance of the richness of Indian forests and plentitude of animals. The natural elements: hills, ravines, wind, birds, animals, trees and the natural background constitute the chief characterization of the stories. But the narratives are camouflaged because it can be analyzed as an encounter between the colonial power and animals, as "animals sometimes constituted a vital subsidy to an often precarious imperial enterprise,.." (MacKenzie,1997, p.7) The colonial modernity coincided with the hunting practices which they tried to designate with the sporting activities. And these hunting practices fabricate both the lives as is the view of Timothy Laurie, "Humanism fabricates the human as much as it fabricates the non-human animal." (Laurie, 2015, p.143) The terror in the hearts of Kumaoni people of the maneaters gives a tense background to the narratives. Since the declaration of the writer in the author's note regarding the nature of the tigers "Human beings are not the natural prey of tigers, and it is only when the tigers have been incapacitated through wounds or old age that, in order to live, they are compelled to take a diet of human flesh." (Corbett, 2015, p.vii), raises the question over the human interference in the declining of the natural food of the wild animals. It is also a question on the careless hunting tradition which leaves the animals wounded and assists in turning them to be man-eaters. Primarily, this collection can be read out as the conflict between the wildlife and human life as both are negatively impacting each-other. World Parks Congress defines "Human-wildlife conflict occurs when the needs and behavior of wildlife impact negatively on the goals of humans or when the goals of humans negatively impact the needs of wildlife." (qtd. in Madden, 2004, p.248) The multilayered implications in this conflict present a whole political and cultural scenario, which consists of the different forms of domination, practiced and regulated by the colonials during the colonization in India.

\section{Hunting: a schism between wild life and human life}

If the so called carnivores had been the inborn man eaters, the co-existence of the wildlife and human life could never be possible. In the early twentieth century, the Indian villages, notably at the fringes of the jungles, were highly dependent on the resources provided by the forests, for their livelihood. Although the animals harmed the people, it was less accounted for because it was tolerable. The defamation of the big animals as precarious always, could not be justifiable. Jim Corbett deplores such type of knowledge over jungles and animals,

I think of a small boy...wandering through the jungles of the terai and bhabar in the days when there were ten tigers to everyone that now survives; sleeping anywhere he happened to be when night came on, with a small fire to give him company and warmth, wakened at intervals by the calling of tigers, sometimes in the distance, at other times near at hand; 
throwing another stick on the fire and turning over and continuing his interrupted sleep without one thought of unease; knowing from his own short experience and from what others, who like himself had spent their days in the jungles, had told him, that a tiger, unless molested, would do no harm;... (Corbett, 2015, p.xi-xii)

The author's note signifies the nature of tigers that don't turn to human flesh usually. But the subsequent stories show a stark dissension with the author's note as the tigers are deeply engaged in human killings. The man-eating animals have become the reason of complete havoc in the suburban villages. There is a reign of terror in Champawat man-eater area, "[a]nd that one coming from the outside should feel that he had stepped right into a world of stark realities and the rule of the tooth and claw, which forced man in the reign of sabre-toothed tiger to shelter in dark caverns." (Corbett, 2015, p.14) It ignites the extent of disturbance, done to the tiger, by the humans' mode of modernization which has taken every non-human as secondary and an object to hunt. Champawat man-eater is responsible for four hundred and thirty-six human kills. And it was directly a product of careless hunting, which was later found by Jim Corbett:

When the tigress had stood on the rock looking down at me I had noticed that there was something wrong with her mouth, and on examining her now I found that the upper and the lower canine teeth on the right side of her mouth were broken, the upper one in half, and the lower one right down to the bone. This permanent injury to her teeth- the result of a gunshot wound- has prevented her from killing her natural prey, and had been the cause of her becoming a man-eater. (Corbett, 2015, p.26).

In the context of this text, the two preeminent reasons have been analyzed for the tigers and leopards turning to be man-eaters: wound and the scarcity of their natural food. Both are directly related to the act of hunting. Corbett said, "Leopards, unlike tigers, are to a certain extent scavengers and become man-eaters by acquiring a taste for human flesh when unrestricted slaughter of game has deprived them of their natural food." (Corbett, 2015, p.xiii) Here, the argument is that 'hunting' functions twofold: the creation of the man-eaters and an apparatus for colonial political and cultural practice of dominance. Joseph Sramek commented on tiger hunting, "British tiger hunting represented imperial domination not just of India's politics but also of its natural environment." (Sramek, 2006, p.661) Through hunting, the natural world of India was being colonized and it can also be analyzed as an opportunity to make the colonials superior by their access to control the endangered animals. Similarly, the Britons tried to establish their superiority through the other projects also like the Great Trigonometric Survey of India in $19^{\text {th }}$ century, embedded with the power and control over the native territory by mapping it out. Matthew Edney commented on the GTSI, "Its continued existence stemmed not from its utility but from its embodiment of cultural values. It struck a cultural nerve in providing the image of system, uniformity, accuracy and precision in accordance with the contemporary enlightenment concerned with rationality and progress..." (qtd. In Sarkar, 2012, p.1)

The colonials added more spice to the act of slaughtering by designating this 'sport' or game. Jim Corbett's emphasis on hunting as 'sports' gives the preliminary idea of loss, done to the wild animals in the colonial period. He remarks, "I was new to this game of man-eating hunting." (Corbett, 2015, p.19) Hunting was excessively in vogue before the arrival of Jim Corbett as a full grown sportsman. He brought up seeing hunting as an inseparable part of the life stratum of the colonials in India, which had a great impact on him. Colonization of the wild animals or nature (as a whole) was a more comprehensive apolitical rink of life. The Forest Act 1878 reserves the government forest area and empowers the government forest officials which obliquely licensees colonial hunters and degraded the native hunters only to poachers. (emphasis mine). Even the 
establishment of the zoos/game parks in the $19^{\text {th }}$ century is embedded with entertainment purposes but regulated through the political power relations. The zoo formation had the social, aesthetic, economic, political and scientific significance for the Britons. The collection of the wild species and preservation sound the colonials' concern over the increasing loss of game/sports, in the first phase of zoo formation. Kisling has termed the European sensibility of establishing zoos with the "utilitarian or mechanistic values." (Kisling, 2001, p.256) The anthropocentric perspective made the animals a badge of power and dignity. "Early captive collections and wildlife (or game) parks in India were for pleasure, aesthetic and humanitarian, as well as for power and the hunt..." (Kisling, 2001, p.257)

The hunt of the animals: bear, ghooral, deer, sambhar, mahsheer, snakes, birds and others were unrestricted. The privilege in slaughtering these animals was more self satisfactory:

Lying in an uncomfortable position and shooting up to an angle of sixty degrees at a range of 200 yards at the small white mark on the ghooral's throat, there did not appear to be one chance in a million of the shot coming off, and yet the heavy lead bullet driven by black powder had not been deflected by a hair's breadth and had gone true to its mark, killing the animal instantaneously. (Corbett, 2015, p.8)

Although this game was full of thrill, endurance and audacity but the careless shot was resulting in the fatal wounds to the animals. Consequently, the man-eaters destroyed many families, where they were being looked upon as devils, as a person reports regarding Champawat man-eater, "This is the shaitan that killed my wife and my two sons." (Corbett, 2015, p.25) And a perilous image of the animals was being projected and maintained prevalence in the present age too. The expressions of the writer like, "On reaching the dead goat he (bear) sat down and took it into his lap, and as he started nosing the goat, I fired. Maybe I hurried over my shot, or allowed too much for refraction; anyway the bullet went low and struck the bear in the stomach instead of in the chest." (Corbett, 2015, p.66) show the ruthless hunting of the animals. Even to fulfill the superstitions of the hunter cum sportsman, snakes were killed only for an auspicious sign. "My own private superstition concerns snakes. When after man-eaters I have a deep-rooted conviction, that, however much I may try, all my efforts will be unavailing until I have first killed a snake." (Corbett, 2015, p.149) Mahseers were being killed in large numbers for the meals. The writer admitted, "I killed sufficient mahseer to feed the camp." (Corbett, 2015, p.193) The Champawat man-eater, the Chowgarh man-eaters and the Thak man-eater were among the wound affected tuned man-eaters. The hunting was being done at the large scale and in the trophy form, which was causing these animals to suffer immensely. The Chowgarh tigress became doubly dangerous as her cub was hunted mistakenly by Jim Corbett.

The tigress's claws were broken, and bushed out, and one of her canine teeth was broken, and her front teeth were worn down to the bone. It was these defects that had made her a man-eater and were the cause of her not being able to kill outright- and by her own efforts- a large proportion of the human beings she had attacked since the day she had been deprived of the assistance of the cub, I had, on my first visit shot by mistake. (Corbett, 2015, p.96)

The Thak tigress had also the same fate. She, too, had been preyed. Her wound, turned to be septic which affected not only her rather the whole vicinity, a prey to her.

Her dark winter coat was without a blemish, and in spite of her having so persistently refused the meals I had provided for her she was encased in fat. She had two old gun-shot wounds, neither of which showed on her skin. The one in her left shoulder, caused by 
several pellets of homemade buckshot, had become septic, and when healing the skin, over quite a large surface, had adhered permanently to the flesh. To what extent this wound had incapacitated her it would have been difficult to say, but it had evidently taken a very long time to heal, and could quite reasonably have been the cause of her having become a man-eater. (Corbett, 2015, p.223)

The gun-shot was the characteristic of the colonial hunt. It was a kind of technological advancement, showing the superiority of the culture over the nature. The development of the firearms in the $19^{\text {th }}$ century empowered the hunting ways of man as it facilitated the hunting expeditions in comparison to the traditional ways of hunting. This mastery over the wild animals and jungles of India was crucial to the British social, political and cultural advancement of the colonials. MacKenzie says, "[a]n understanding of hunting requires an attempt to come to grips with the technical development of firearms in the nineteenth century." (MacKenzie, 1997, p.1) The dual role of the gun-shot was not being apprehended by the colonized. Their reliance on the white hunter, having a gun, as their savior, was actually the face behind the damage, they had been undergoing for the years together. The detriment done to the native people by endangering their animals was camouflaged with the benevolent policy of rescue missions of the government. The colonial masters were deeply involved in providing the firearms. "The Tahsildar had let it be known that he would turn a blind eye towards all unlicensed firearms, and further that he would provide ammunition where required; and the weapons that were produced that day would have stocked a museum." (Corbett, 2015, p.22) This was the advancement which was assisting the colonials to rule over the colonized natives and their nature.

On one hand where hunting was harming the wildlife and environment, at the same time, it was the birth of the benevolent hunter cum savior 'sahib' for the local native people who were highly dependent on white masters for their safety from the carnivorous. Swati asserts, "Hunting displayed the power of the colonial state and its domination over nature and natives." (Swati, 2009, p.1) The British rule established the different ways of dominating the colonized subjects; MacKenzie termed hunting as, "spectacular display of white dominance." (MacKenzie, 1997, p.7) similarly hunting and the acceptable epitome of savior for the local people can also be analyzed as a prominent part of the reigning policies of the Britons. (emphasis mine). Since it was a means to come close to the native people and generate knowledge about them. The reliance of the native people on the colonial hunters, particularly Jim Corbett, to get rid of the dangerous animals was the benign dictum over the colonized. The apotheosis of savior, results in the incarnation of sahib. MacKenzie put the view that hunting played an important role in the establishment of "British imperial masculinity." (qtd. In Sramek, 2006, p.662)

\section{Jim Corbett: a hunter and a sahib}

Man-eaters' hunting expeditions proved to be a means in the cognizance of the various regions of the country through the close acquaintance with the language and culture of the colonized people. In the view of Arthur Brinckman, "If our officers had not always been such good sportsmen, we should have had greater difficulty in holding India. An officer in search of sport learns the language, gets a knowledge of the country and the people; all this is to our good." (Brinckman, 1865, p.127) Although Jim Corbett was playing the role of rescuer for the local people; his duties for the colonial administrators were at the center. Shooting with the gun was an instrument of power. Colonial ideology made the colonized subjects intrinsically inferior which needed to be governed and directed. In the mission of hunting the man-eaters, the local group of 
people/hunters played only the supplementary roles because "Native Indians were debarred from owning firearms..." (Pandian, 2001, p.83) The information and assistance provided by the colonized was put aside. And the hunter cum sportsman inhaled as the incarnation of the greatest rescuer, termed as sahib. The patronizing attitude had simplified the colonial access and influence on the colonized people. "[c]olonization could be (re)presented as a virtuous and necessary 'civilizing' task involving education and paternalistic nurture." (Ashcroft et.al, 2007, p.41) The colonialist treatment of the indigenous flora and fauna, in the fashion of hunting was naturalized in a way that shooting became a right of the elites. Edward Said termed the various Western ways of domination as their style, "Orientalism as a Western style of dominating, restructuring, and having authority over the Orient." (Said, 2001, p.3) Hunting proved to be a considerable means of social and provincial control. The narratives of Jim Corbett convince that he was working for the British administration, deeply involved in hunting and the big game of sighting the big animals. His ambivalence comes to the fore when he, at times, drives out at the urges of the villagers to work for their local interests. He had assisted in endangering the indigenous fauna. He admitted, "I have sometimes only wounded leopards and tigers, who have rampaged round before being quietened by a second or third shoot." (Corbett, 2015, p.33) The idea of game was the most pleasurable pastime for Corbett. He worked at the urges of the villagers too.

After breakfast on Sunday morning the Headman of Dalkania paid me a visit and requested me to shoot them some game before I left. The request was gladly acceded to, and half an hour later, accompanied by four villagers and one of my own men, and armed with a 275 rifle and a clip of cartridges, I set off for the hill..." (Corbett, 2015, p.62)

He was being appointed by the British officials to work in the man-eater affected areas from time to time. The need of the colonized to civilize and to govern was making the high officials to protect the affected area. "In March 1930, Vivian, our District Commissioner, was touring through the man-eater's domain, and on the $22^{\text {nd }}$ of the month I received an urgent request from him to go to Kala Agar, where he said he would await my arrival." (Corbett, 2015, p.83) Conferences were being held to discuss over the problem of dealing with the man-eaters. "After the Chowgarh tiger had been accounted for, I was reminded by Baines, Deputy Commissioner, Almora, that only a part of my promise made at the conference had been fulfilled, and that the Mohan tiger was next on the list." (Corbett, 2015, p.115)

Shooting for trophy was an act of prestige. The Bachelor of Powalgarh was the most sought after tiger for hunting. The environmental loss in order to accomplish the hunting cum sporting activities was being ignored. "In 1930 the Forest Department started extensive fellings in the area surrounding the Bachelor's home..." (Corbett, 2015, p.99) In the jungles of Kaladhungi, Corbett first met this tiger when he exclaimed, "It was in this glade, which for beauty has no equal, that I first saw the tiger who was known throughout the United Provinces as "The Bachelor of Powalgarh', from 1920 to 1930 was the most sought-after big game trophy in the province." (Corbett, 2015, p.97) A number of white hunters got involved in pursuing the bachelor but resulted in the eradication of natural wealth of the Indian jungle. The description of this tiger varied from person to person. "Anderson described him as being as big as a Shetland pony, Edye said he was as big as a donkey." (Corbett, 2015, p.99) In achieving this trophy, so many unsuccessful attempts had taken place. Corbett put the view, "The winter following these and other unsuccessful attempts, I took Wyndham, our commissioner, who knows more about tigers than any other man in India, to a fire track skirting the upper end of the ravine in which the Bachelor lived..." (Corbett, 2015, p.99) And finally it was killed ruthlessly. "[a]nd on receiving my two bullets he rolled over on his side without making a sound." (Corbett, 2015, p.110) The Pipal 
Pani tiger was also killed for the ostentation of winning a trophy. The innocence of this tiger made the writer to call him his friend. He was the animal who was mistakenly shot for a pig. He was harmless to anyone. "Once before when badly wounded he had passed through the settlement without harming man or beast..." (Corbett, 2015, p.171) But he was slaughtered only for misconception. "It was only then I found he had been shot under a misapprehension...pleasure at having secured a magnificent trophy- he measured 10'3" over curves and his winter coat was in perfect condition..." (Corbett, 2015, p.173)

Hunting of the man-eaters assisted Jim Corbett to become a respected sahib who showed physical and mental fortitude in pursuing man-eaters and protecting the villagers. In persuasion of the hunt, he came closer to the Indian jungles and the rural people. He found great support from the villagers in his tasks of man-eaters hunting. He would offer them meat in compensation of the assistance, they provided to him. Rene Maunier has put the view in regard to the colonial ideology of benevolent/paternalistic attitude of the white hunters,

The gentleman is not only the polite and polished man, he is more, especially the man who knows how to command; the imperial man in a certain sense, who having powers, makes it his duty and his right to use them for the common welfare. The ideas of authority- as power and authority- as duty are the heritage of an aristocratic tradition. (30)

The ambivalence in the narratives of Corbett is in his duties between his colonial identity and his colonized responsibilities. Distinguished from his fellow hunters of that time, he was able to sympathize with the natives, and promised to get rid them of danger. He, often, denied to be categorized any sort of officer by the rural people. Wandering in search of the Mohan man-eater in Kartanoula, he was confronted with a lady, asking several questions. He said, "[ $t$ ]hat I was not an officer of any kind, and that the sole purpose of my visit was to try to rid them of the maneater." (Corbett, 2015, p.119) Spending his life in the Indian jungles and with the rural people, he developed a harmony with the local people. His friendship with Madho Singh has been quoted at times by him. He did not even mind to shoot a sleeping animal, which was against his sportsmanship. He added the arguments for killing the sleeping Mohan-eater,

These arguments were (a) the tiger was a man-eater that was better dead than alive, (b) thereafter it made no difference whether he was awake or asleep when killed, and (c) that had I walked away when I saw his belly heaving up and down I should have been morally responsible for the deaths of all human beings he killed thereafter. (Corbett, 2015, p.140)

He accentuated his responsibility as the rescuer of the natives in spite of the adverse circumstances. His differentiation between fair and the unfair was critical to his benevolent image for the natives. This sort of hunting had a colonial cultural impact when the hunter needed specific forms of knowledge about the natural elements: hills, ravines, birds, animals, wind etc., and having this information, the man-eating hunting task taken as nobler undertaking. It helped in the creation of the colonials as superior and paternalistic in nature. The colonial administrator/s was filled with a sense of gaining the knowledge of the native culture which was a tool for smooth functioning of their rule. Metcalf quotes about Warren Hastings, to exemplify the ruling exercises,

Shaped by the Enlightenment ideal of understanding all cultures...'cultivation of language and science' in India a way to secure the 'gain of humanity'. Yet such learning would also be 'useful to the state', as it would 'lessen the weight of the chain by which the natives are held in subjection' and at the same time 'imprint on the hearts of our own countrymen the sense and obligation of benevolence'. (Metcalf, 2008, p.10) 
The petition of Govind Singh, headman of the village Jharat, Garhwal, to Jim Corbett in 1933, was the evidence of the faith, which the native people were having only in Jim Corbett. The extract of the petition is,

We have heard that your kind self have killed many man-eater tigers and leopards. For this you have earned a good name specially in Kumaon revenue Division. The famous man-eater leopard of Nagpur has been shoot by you. This is the voice of all the public here that this tiger also will be killed only by you." (Corbett, 2015, p.16o)

The promises done by Corbett to the local people were being fulfilled with firm determination. The hunting by Jim was embedded with ambivalence. His relationship with the colonials was quite apparent. He was amongst the colonial hunters who were imperiling the indigenous fauna. At the same time his paternalistic nurture for the native people was quite paradoxical when he himself was engaged in the endangering situations and was quite content in saving the human lives. His Thak man-eater narrative mentions,

There have been occasions when life has hung by a thread and others when a light purse and disease resulting from exposure and strain have made the going difficult, but for all these occasions I am amply rewarded if my hunting has resulted in saving one human life. (Corbett, 2015, p.223)

\section{Conclusion}

The study finds a constant strife between nature and culture through the attempts in establishing the superiority of one over the other. Man, having a 'gun', an emblem of culture and power shows his supremacy whenever gets chance and the reaction of nature / 'tigers' through man slaughtering, violates coexistence of man with nature unlike the preexistence of both. Although the colonials introduced hunting as an entertainment/ sporting exercise, its precarious consequences disturbed not only the wildlife but the human life as well. Hunting becomes the site for the embedded power of the colonials and also a means to control the native people through making them free from the terror of the man-eaters. The jungles in the Kumaon region which were the source of living for the rural people, transform into the haunting places due to the possibilities of man-eaters' arrival. The modernity which privileged culture or the material progress over the nature has led to the quieting of mute animals in the clamorous human world. The narratives are a critique of the human-centred approach where the existence of other is challenged. The study also finds Jim Corbett, caught between two sensibilities: being a white hunter and a rescuer of the native people with whom he passed a long time of his life and address them as his friends. Although he shares close affinity with the rural folk, he remained a sahib for them. It echoes with what Storey said, "The hunt symbolized the triumph of culture over nature and of colonist over colonized." (Storey, 1991, p.149) The paper is limited to explore the cultural aspects of hunting and man-animal relationship in terms of power and domination and leaves the gap for exclusive Animal Studies for further research. 


\section{References:}

Alexander, R.D.T and Leaje, A.M. (1932). Some Signposts to Shikar. Calcutta: Fred R Grenyer.

Ashcroft, B., Griffiths, G., \& Tiffin, H. (2007). Post-colonial studies: The key concepts. Taylor and Francis eLibrary.

Bore, B. (1924). Guide to Shikar on the Nilgiris. Madras: S.P.C.K. Depot.

Brinckman, A. (1865). The Rifle in Cashmere. London: Smith, Elder \& Co. Google Book Search.

Cooper, F. (2005). Colonialism in Question. California: University of California Press. Retrieved from <http://bookzz.org/ireader/494224>

Corbett, J. (2015). Man-Eaters of Kumaon. New Delhi: Oxford University Press. (First published in 1944)

Hegel, G.W.F. (2001). The Philosophy of History. J.Sibree (Trans.) Charles Hegel. (Preface.)

Ontario: Batoche Books. Retrieved from < http://bookzz.org/ireader/754792>

Kisling, V.K. Jr. (2001). (Ed.) Zoo and Aquarium History: Ancient Animal Collections to Zoological Gardens. USA: CRC Press. Retrieved From <http://bookzz.org/book/667502/576391>

Laurie,T. (2015). "Becoming Animal is a Trap for Humans: Deleuze and Guattari in Madagascar”. In Deleuze and the Non/Human. Ed. Jon Roffe and Hannah Stark. UK: Palgrave Macmillan.

MacKenzie, J.M. (1997). The Empire of Nature: Hunting, Conservation and Imperialism. Manchester University Press Series. (Studies in Imperialism)

Madden, F. (2004). "Creating Coexistence between Humans and Wildlife: Global Perspectives on Local Efforts to Address Human-Wildlife Conflict." Human Dimensions of Wildlife, Vol. 9. (247-257). Taylor and Francis Inc. DOI: 10.1080/10871200490505675

Maunier, R. (2013). The Sociology of the Colonies [Part 1]: An Introduction to the Study of Race Contact. Routledge.

McCarthy, T. (1998). "Introduction." In Jürgen Habermas. The Philosophical Discourse of Modernity. Frederick Lawrence. (Trans.) UK: Polity Press and Blackwell Publishers Ltd.

Metcalf, T. R. (2008). The New Cambridge History of India, Vol. III, 4: Ideologies of the Raj. Cambridge Histories Online, Cambridge University Press. Retrieved from <http://bookzz.org/ireader/887601>

Nietzsche, F., \& Hollingdale, R. J. (1996). Nietzsche: Human, all too human: A book for free spirits. Cambridge University Press.

Pandian, A.S. (2001). "Predatory Care: The Imperial Hunt in Mughal and British India." Journal of Historical Sociology, Vol. 14, No.1. (79-107). Blackwell Publishers.

Said, E. (2001). Orientalism. Gurgaon: Penguin Books India.

Sarkar,O. (2012). "The Great Trigonometrical Survey: Histories of Mapping 1790-1850". eTraverse, The Indian Journal of Spatial Science, Vol. III, No.1, Article 4 (1-6).

Sramek, J. (2006). " "Face Him like a Briton": Tiger Hunting, Imperialism, and British Masculinity in Colonial India, 1800-1875". Victorian Studies, 48(4), 659-680. Retrieved from <http://www.jstor.org/stable/4618910>

Storey, W. (1991). "Big Cats and Imperialism: Lion and Tiger Hunting in Kenya and Northern India, 18981930". Journal of World History, 2(2), 135-173. Retrieved from <http://www.jstor.org/stable/20078498>

Swati, S. (2009). Sahibs and Shikar: Colonial Hunting and Wildlife in British India: 180o-1935. (Doctoral Dissertation). Retrieved from Duke University Libraries < http://hdl.handle.net/10161/1647> 
The Indian Forest Act 1878. Web. 10 Apr. 2017. Retrieved From <http://bombayhighcourt.nic.in/libweb/oldlegislation/1878.o7.pdf>

Parul Rani, a research scholar in English in the Department of Humanities and Social Sciences, IIT Roorkee.Email: parulnet.e@gmail.com

Nagendra Kumar, a professor of English in the Department of Humanities and Social Sciences, IIT Roorkee.Email:naguk2o@gmail.com 